\title{
SNP discovery from liver transcriptome in the fish Piaractus mesopotamicus
}

\author{
Vito Antonio Mastrochirico-Filho ${ }^{1} \cdot$ Milene Elissa Hata $^{1} \cdot$ Lucas Seiti Sato $^{1} \cdot$ \\ Paulo Henrique Jorge ${ }^{1}$ - Fausto Foresti ${ }^{2}$ - Manuel Vera Rodriguez ${ }^{3}$. \\ Paulino Martínez ${ }^{3} \cdot$ Fábio Porto-Foresti ${ }^{4}$ Diogo Teruo Hashimoto ${ }^{1}$ (D)
}

Received: 1 February 2016/Accepted: 3 February 2016/Published online: 9 February 2016

(C) Springer Science+Business Media Dordrecht 2016

\begin{abstract}
Pacu (Piaractus mesopotamicus) is a Neotropical freshwater fish threatened by overfishing, and one of the species of highest commercial value for aquaculture. Genetic variability analysis through molecular markers is an essential technique to genetic management of the wild and cultivated stocks. The main objective of this study was to identify and validate gene-associated SNPs of the liver transcriptome of pacu. Through genetic analysis in one natural population (Paraná River), 32 polymorphic SNPs were successfully genotyped and validated, some of them related to immune system genes. The observed and expected heterozygosity ranged from 0.059 to 0.706 and 0.058 to 0.507 , respectively. All loci were in HardyWeinberg equilibrium $(P>0.05)$. Our results showed useful genomic resources for pacu, with applicability in conservation purposes and aquaculture industry by using SNPs markers.
\end{abstract}

Keywords NGS $\cdot$ Pacu $\cdot$ Aquaculture $\cdot$ Genetic variability

Pacu (Piaractus mesopotamicus) is a Neotropical freshwater fish widely distributed in floodplain areas of the $\mathrm{La}$

Diogo Teruo Hashimoto

diogo@ caunesp.unesp.br

1 Centro de Aquicultura da Unesp, Universidade Estadual Paulista, Jaboticabal, SP, Brazil

2 Departamento de Morfologia, IBB, Universidade Estadual Paulista, Botucatu, SP, Brazil

3 Departamento de Genética, Facultad de Veterinaria, Universidad de Santiago de Compostela, Lugo, Spain

4 Departamento de Ciências Biológicas, FC, Universidade Estadual Paulista, Bauru, SP, Brazil
Plata Basin. Wild populations of pacu are threatened by overfishing (Resende 2003), particularly in Brazil (in São Paulo State, according to the Decree $\mathrm{n}^{\circ}$ 56.031, SSP, 2010), since this species is considered of high commercial value, with large-scale catches by the industrial and recreational fisheries (MPA 2011; IBGE 2014). Furthermore, this nonmodel fish is very important for aquaculture and represents one of the most cultivated species in Brazil, and in aquaculture from other countries in South America (Colombia, Peru, Venezuela and Argentina) and Asia (China, Myanmar, Thailand and Vietnan) (Flores Nava 2007; Honglang 2007; FAO 2010).

Genetic studies directed to this species are still insufficient and limited in few microsatellites and mitochondrial sequences (Calcagnotto and DeSalle 2009; Iervolino et al. 2010). SNPs (Single Nucleotide Polymorphisms) are caused by point mutations distributed throughout the genome and they have been frequently used in fish genetic studies (Vera et al. 2013; Zhang et al. 2015; Liu et al. 2016). Moreover, this marker is considered the most adaptable to automation genotyping and able to reveal hidden polymorphisms not detected in others molecular markers (Liu and Cordes 2004). Therefore, due to environmental concerns and economic importance to aquaculture production, the purpose of this study was to develop SNPs marker by liver transcriptome sequencing in pacu, which may provide a better understanding of population structure of this species and the first base information about economically relevant traits for future molecular assisted breeding.

To perform the transcriptome sequencing, samples were collected from liver of individuals (5 juveniles and 5 adults) from three different fish farms and in one wild population, and sequenced on Roche/454 pyrosequencing platform. We obtained 212,545 trimmed reads which were 
deposited in Short Read Archive (SRA) of NCBI, under the accession number SRA312243. De novo assembly strategy was performed using CLC Genomics Workbench (version 7.5.1; CLC bio; Aarhus; Denmark) and yielded 4110 assembled transcripts, as a result of 193,247 reads overlapped $(71,581,413 \mathrm{bp})$ and N50 of $871 \mathrm{bp}$. Functional annotation was attributed to assembled transcripts by BLASTX (cutoff $e$-value 1E-3) through homology searches against NCBI nonredundant protein database, using Blast2Go software. A total of 2051 sequences was identified with the highest homology to Astyanax mexicanus sequences. We found 1665 annotated sequences with Interpro accession numbers and 1773 sequences classified in gene ontology (GO) terms, where cellular and metabolic process were highly represented (Fig. 1). Meanwhile, we have still identified 619 enzyme code numbers from KEGG mapping results which revealed a total of 1023 transcripts mapped to 111 different enzyme pathways, being the most frequent related to purine metabolism, thiamine metabolism and biosynthesis of antibiotics.

SNP calling was performed using CLC Genomics Workbench (version 7.5.1; CLC bio; Aarhus; Denmark). In total, 802 putative SNPs were found in 229 transcripts (Table 1). Abundant and repetitive SNPs in small areas were excluded. After the filtering step, we identify 464 SNPs. For gene location of the SNPs, ORF (Open Reading Frame) regions were found by comparing the sequences against the NCBI protein database (cutoff evalue 1E-10):
Table 1 Putative SNPs identification parameters, through de novo assembly of the pacu (Piaractus mesopotamicus) transcriptome

\begin{tabular}{ll}
\hline SNP features & Value \\
\hline Contig with SNPs & 229 \\
Contig average length (min-max) (bp) & $1461.8(209-5150)$ \\
SNP amount & 802 \\
SNP per kilobase & 2.4 \\
Average coverage of reads (min-max) & $54.8 \mathrm{x}(15-1619 \mathrm{x})$ \\
Transitions & \\
A-G & $301(37.5 \%)$ \\
C-T & $267(33.3 \%)$ \\
Transversions & \\
G-T & $72(9.0 \%)$ \\
A-C & $61(7.6 \%)$ \\
A-T & $52(6.5 \%)$ \\
C-G & $49(6.1 \%)$ \\
Transition:transversion ratio & 2.43 \\
\hline
\end{tabular}

$330(71.1 \%)$ SNPs were distributed in coding regions (cds), being 233 synonymous (50.2\%) and 97 non-synonymous $(20.9 \%)$; 80 SNPs $(17.2 \%)$ were located in $3^{\prime} \mathrm{UTR}$ and $46(10.0 \%)$ in $5^{\prime} \mathrm{UTR}$.

50 SNP loci (2 Multiplex) were selected to perform validation and genotyping analysis with the Sequenom MassARRAY platform, in CeGen (Genotyping National Center, Santiago de Compostela, Spain). The technique is increasingly used in the genotyping of SNPs in fish



GO Terms

Fig. 1 Gene ontology categories of Piaractus mesopotamicus sequences 


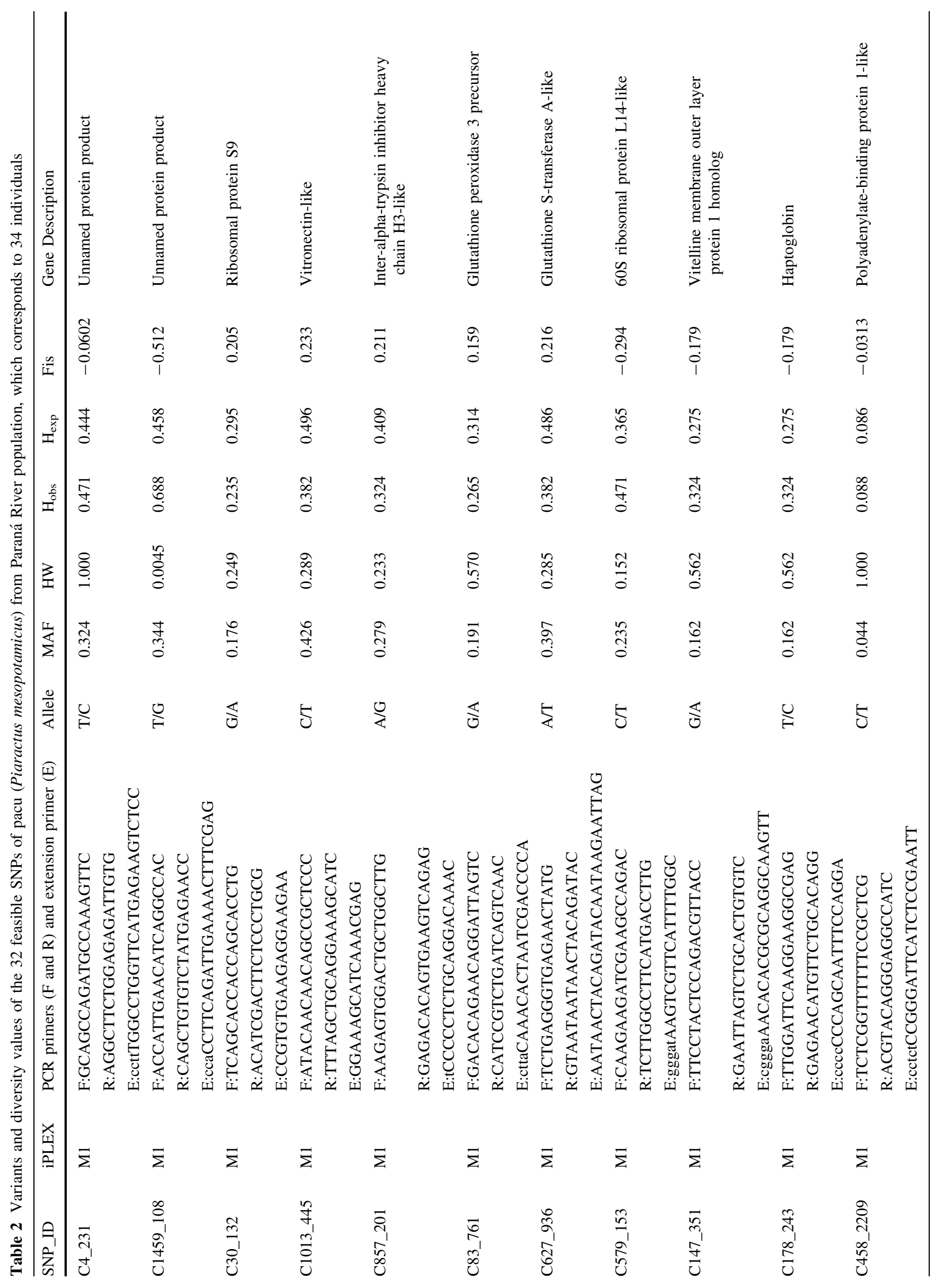




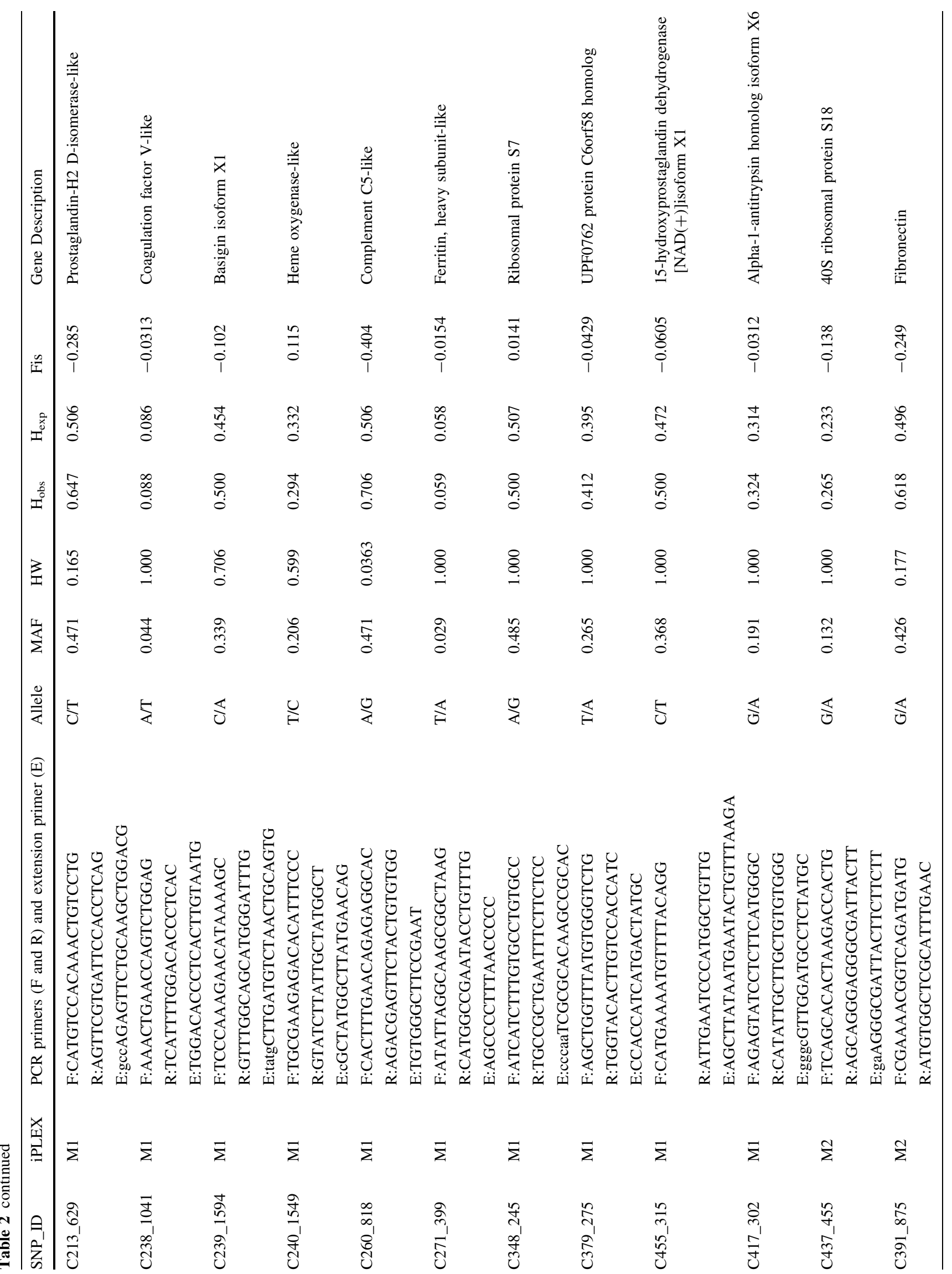




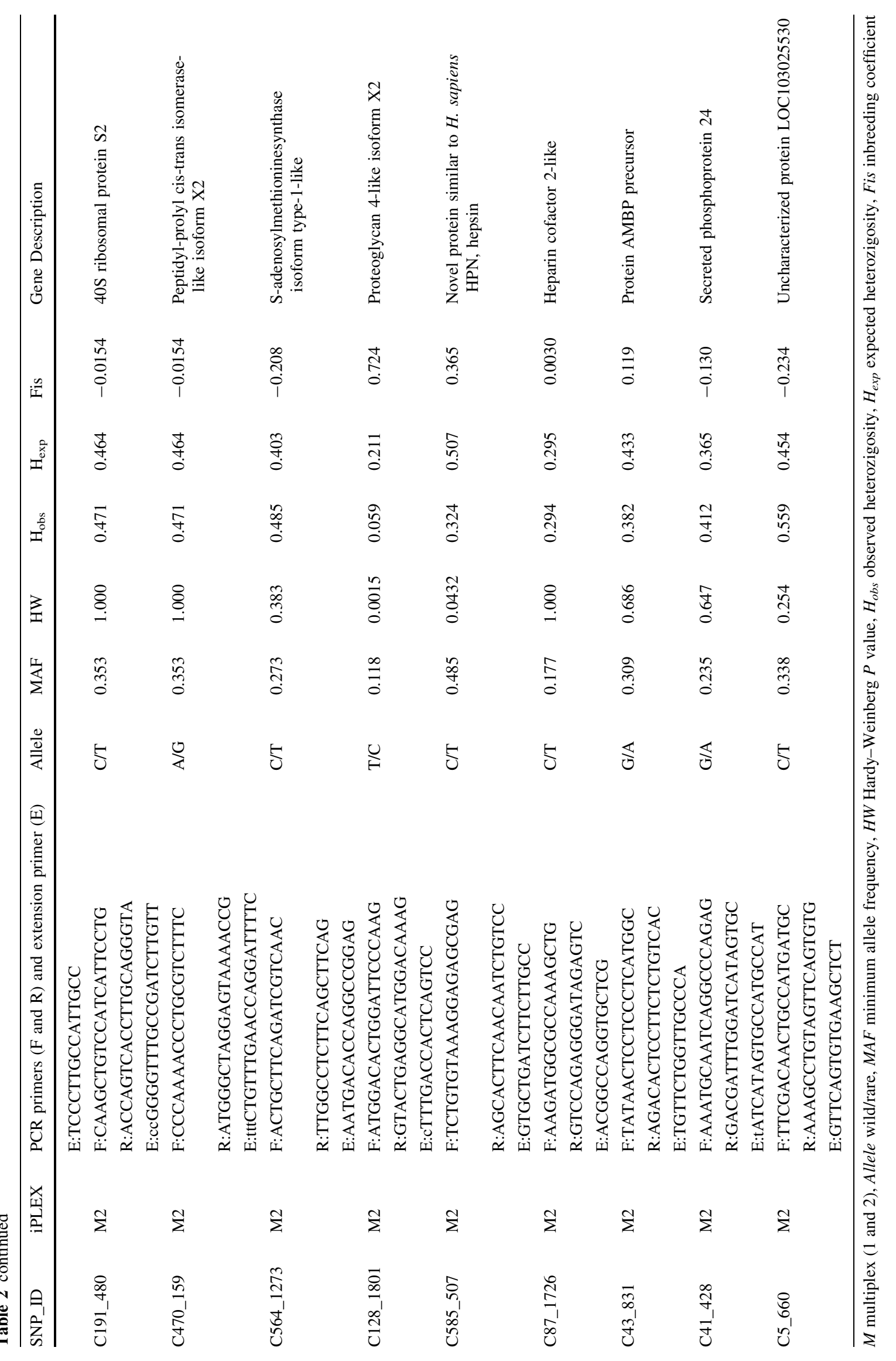


(Willians et al. 2010; Salem et al. 2012) and consists of an extension reaction in which one primer is annealed immediately above the existing polymorphism, that by mass spectrometry, the mass of extended primer is determined (Gabriel and Ziaugra 2004). Some genes of the genotyped SNPs were related to immune system, such vitronectin-like (C1013_445), coagulation factor V (C238_1041) and glutathione S-transferase (C627_936) genes (Table 2).

Statistical genetic parameters to describe the Paraná River population (São Paulo State, Brazil) were obtained through the validation process of 32 feasible polymorphic SNPs $(64 \%)$ in 34 individuals (Table 2). The observed $\left(H_{o b s}\right)$ and expected heterozygosity $\left(H_{\text {exp }}\right)$ were calculated using Cervus 3.0.7 (Marshall et al. 1998). Inbreeding coefficient (Fis), minimum allele frequency (MAF) parameters, conformance to Hardy-Weinberg equilibrium (HW) and Linkage disequilibrium were performed using Genepop 4.0.11 (Raymond and Rousset 1995). Fis parameters were estimated regards Weir and Cockerhsam (1984). The observed and expected heterozygosity ranged from 0.059 to 0.706 and 0.058 to 0.507 , respectively. MAF ranged from 0.029 to 0.485 . Deviation of Hardy-Weinberg equilibrium was not significant after Bonferroni correction $(P>0.0015)$. Significant linkage disequilibrium (LD) was observed between the loci: C178_243/C191_480, C417_302/C41_428, C1013_445/ C585_507, C1013_445/C87_1726 and C239_1594/C87_ 1726. Negative values of Fis values were predominant (heterozygote excess). The present study increases significantly the genetic resources for pacu (Piaractus mesopotamicus), a non-model warmwater species used in aquaculture of several countries, which has high market value, but threatened by overfishing. Furthermore, our SNPs set are useful for pre-breeding genetic programs, particularly to delineate the formation of the best families in terms of genetic variability, as well as to detect genetic structure of wild and farmed stocks of pacu.

Acknowledgments This work was supported by grants from PróReitoria de Pesquisa da UNESP (Prope 07/2015-DTH), Conselho Nacional de Desenvolvimento Científico e Tecnológico (CNPq 446779/2014-8 and 305916/2015-7-DTH; and 130262/2014-5 VAMF), and Fundação de Amparo à Pesquisa do Estado de São Paulo (FAPESP 2014/03772-7-DTH and 2014/12412-4-VAMF).

\section{References}

Calcagnotto D, DeSalle R (2009) Population genetic structuring in pacu (Piaractus mesopotamicus) across the Paraná-Paraguay basin: evidence from microsatellites. Neotrop Ichthyol 7(4):607-616. doi:10.1590/S1679-62252009000400008
FAO (2010) The state of world fisheries and aquaculture-2010 (SOFIA). FAO, Rome

Flores Nava A (2007) Aquaculture seed resources in Latin America: a regional synthesis. In: Bondad-Reantaso MG (ed) Assessment of freshwater fish seed resources for sustainable aquaculture. FAO Fisheries Technical Paper No 501. FAO, Rome

Gabriel S, Ziaugra L (2004) SNP genotyping using Sequenom MassARRAY 7K Platform. Curr Protoc Hum Genet 42:2.12: 2.12.1-2.12.16. doi:10.1002/0471142905.hg0212s42

Honglang H (2007) Freshwater fish seed resources in China. In: Bondad-Reantaso MG (ed) Assessment of freshwater fish seed resources for sustainable aquaculture. FAO Fisheries Technical Paper No 501. FAO, Rome

IBGE (2014) Instituto Brasileiro de Geografia e Estatística. Produção da Pecuária Municipal 2013, vol 41. IBGE, Rio de Janeiro. http://www.ibge.gov.br/home/estatistica/economia/ppm/2013/

Iervolino F, Resende EK, Hilsdorf AWS (2010) The lack of genetic differentiation of pacu (Piaractus mesopotamicus) populations in the Upper-Paraguay Basin revealed by the mitochondrial DNA D-loop region: implications for fishery management. Fish Res 101:27-31. doi:10.1016/j.fishres.2009.09.003

Liu ZJ, Cordes JF (2004) DNA marker technologies and their applications in aquaculture genetics. Aquaculture 238:1-37. doi:10.1016/j.aquaculture.2004.05.027

Liu S, Palti Y, Gao G, Rexroad CE III (2016) Development and validation of a SNP panel for parentage assignment in rainbow trout. Aquaculture 452:178-182. doi:10.1016/j.aquaculture. 2015.11.001

Marshall TC, Slate J, Kruuk LEB, Pemberton JM (1998) Statistical confidence for likelihood-based paternity inference in natural populations. Mol Ecol 7:639-655. doi:10.1046/j.1365-294x. 1998.00374.x

MPA. Ministério da Pesca e Aquicultura (2011) Boletim estatístico da pesca e aquicultura. MPA, Brasília

Raymond M, Rousset F (1995) GENEPOP (version 1.2): population genetics software for exact tests and ecumenism. J Hered 83(6):248-249

Resende EK (2003) Migratory fishes of the Paraguay-Paraná basin excluding the Upper Paraná River. In: Carolsfeld J, Harvey B, Ross C, Baers A (eds) Migratory fishes of South America: biology, fisheries and conservation states. World Bank, Victoria, pp 99-156

Salem M, Vallejo RL, Leeds TD, Palti Y, Liu S et al (2012) RNA-Seq identifies SNP markers for growth traits in rainbow trout. PLoS One 7(5):e36264. doi:10.1371/journal.pone.0036264

Vera M, Alvarez-Dios J, Fernandez C, Bouza C, Vilas R et al (2013) Development and validation of Single Nucleotide Polymorphisms (SNPs) markers from two transcriptome 454-runs of turbot (Scophthalmus maximus) using highthroughput genotyping. Int J Mol Sci 14:5694-5711. doi:10. 3390/ijms 14035694

Weir BS, Cockerhsam CC (1984) Estimating F-statistics for the analysis of population structure. Evolution 38:1358-1370

Willians LM, Ma X, Boyko A, Bustamante CD, Oleksiak MF (2010) SNP identification, verification, and utility for population genetics in a non-model genus. BMC Genet 11:32. doi:10. 1186/1471-2156-11-32

Zhang HW, Yin SW, Zhang LJ, Hou XY, Wang YY (2015) Development and validation of single nucleotide polymorphism markers in Odontobutis potamophila from transcriptomic sequencing. Genet Mol Res 14(1):2080-2085. doi:10. $4238 / 2015$ 